\title{
A new species of Hypostomus Lacépède, 1803 (Siluriformes: Loricariidae) from the upper rio Paraná basin, Southern Brazil
}

\author{
Fernando C. Jerep*, Oscar A. Shibatta** and Cláudio H. Zawadzki***
}

A new species of Hypostomus with large and spaced light roundish spots is described from the upper rio Paraná basin. Hypostomus multidens new species is distinguished from all remaining congeners with light spots on a darker background by two independent characters: the presence of teeth with two symmetrical cusps, and a high tooth number in each dentary (122267, mean 196.8) and premaxilla (115-260, mean 190.8).

Uma nova espécie de Hypostomus com pintas claras grandes e espaçadas é descrita para a bacia do alto rio Paraná. Hypostomus multidens nova espécie distingue-se de todas as outras congêneres com pintas claras em um fundo escuro por duas características independentes: a presença de dentes com cúspides simétricas, e um elevado número de dentes em cada dentário (122-267, média 196.8) e pré-maxilar (115-260, média 190.8).

Key words: Cascudos, Catfishes, Hypostominae, Neotropics, Taxonomy.

\section{Introduction}

Presenting practically the same range of the family Loricariidae throughout Central and South America, the Hypostominae is the largest subfamily, with about 31 genera and 366 valid species (Armbruster, 2004). The genus Hypostomus Lacépède, 1803 is one of the most diverse and complex groups of South American catfishes, due mainly to incomplete species descriptions, limited knowledge about their distribution patterns, and the particularly high intraspecific variability in morphology and color pattern (Reis et al., 1990; Weber, 2003). Regional revisionary studies are an alternative used for some authors to deal with the complex taxonomical questions of Hypostomus, as demonstrated by Boeseman (1968) for the species from Suriname, Weber $(1985,1986,1987)$ for Hypostomus from Paraguay, Reis et al. (1990) for species from Southern Brazil, Mazzoni et al. (1994) for species from lower rio Paraíba do Sul, in the State of Rio de Janeiro, Hollanda Carvalho \& Weber (2004) for the Hypostomus cochliodon group from middle and lower Amazon system, and Oyakawa et al. (2005), for Hypostomus from rio Ribeira de Iguape drainage, in the States of São Paulo and Paraná.

Currently the genus comprises more than 130 nominal species [107 species considered valid by Weber (2003) and 134 by Armbruster (2004)], and the maximum diversity in number of species of Hypostomus occurs in rivers of the Paraná-Paraguay system (Weber, 2003). Twenty species of Hypostomus are recognized in the upper rio Paraná basin (Weber, 2003) and they may be included in two artificial groups based on color pattern: one with species that have dark roundish dots on a lighter background $[H$. ancistroides (Ihering, 1911); H. brevis (Nichols, 1919); H. commersoni Valenciennes, 1836; H. fluviatilis (Schubart, 1964); $H$. hermanni (Ihering, 1905); H. iheringii (Regan, 1908); H. nigromaculatus (Schubart, 1964); H. paulinus (Ihering, 1905); H. ternetzi (Boulenger, 1895); H. topavae (Godoy, 1969)], and another with species that have light roundish dots or irregular light marks on a darker background [H. albopunctatus (Regan, 1908); H. lexi (Ihering, 1911); H. margaritifer (Regan, 1908); H. meleagris (Marini, Nichols \& La Monte, 1933); $H$. microstomus Weber, 1987; H. regani (Ihering, 1905); $H$. scaplyceps (Nichols, 1919); H. strigaticeps (Regan, 1908); H. tietensis (Ihering, 1905); H. variipictus (Ihering, 1911)]. Although Ihering (1905, p.559) described Hypostomus tietensis as having "upper part of head with dark stripes or vermiculations" and "body with dark spots", based on one specimen from rio Tietê, we included $H$. tietensis within the group of species that have light roundish dots on a darker background based on the examination of the holotype and several specimens from upper rio Tietê basin, that have the

\footnotetext{
*Laboratório de Ictiologia, Museu de Ciências e Tecnologia, PUCRS, Av. Ipiranga 6681, 90619-900 Porto Alegre, RS, Brazil.

**Museu de Zoologia da Universidade Estadual de Londrina, Departamento de Biologia Animal e Vegetal, Rodovia Celso Garcia Cid PR445, Km 380, 86051-990 Londrina, PR, Brazil. shibatta@uel.br

***Universidade Estadual de Maringá, Departamento de Biologia, NUPELIA, Av. Colombo 5790, 87020-900 Maringá, PR, Brazil.
} 
body coloration formed by light stripes irregularly spaced combining to form vermiculations on a darker background. However, this color pattern is complex and it is sometimes difficult to define whether there are light marks on a darker background or dark marks on lighter background. Probably examination of the color pattern of only the holotype might have led R.von Ihering to fall into a mistake.

The main objective of this study is the description of a new species of Hypostomus from the upper rio Paraná basin. A complete review of the nominal species of Hypostomus from the rio Tietê basin, including the presentation of an identification key is currently being prepared by C. H. Zawadzki, H. A. Britski and C. S. Pavanelli (pers. comm.).The new species described herein is included in the group of species with light roundish dots on a darker background.

\section{Material and Methods}

All measurements were taken point to point with digital calipers to the nearest $0.1 \mathrm{~mm}$, under a dissecting microscope when necessary. Measurements and counts of bilaterally symmetrical features were taken from the left side of the body whenever possible; if a feature was missing or broken on the left side, it was examined on the right side.

Measurements follow Weber (1985), Fisch-Muller et al. (2001), and Pereira \& Oyakawa (2003). Counts and nomenclature of median plate series were taken according to Schaefer (1997) with the modifications of Oyakawa et al. (2005). Additional measurements and counts include: eye-nostril distance (least distance between anterior orbital margin and nostril), plates between dorsal and adipose fins (number of plates in dorsal series between insertion of last dorsal-fin branched ray and origin of adipose-fin spine), and plates between adipose and caudal fins (number of plates in dorsal series from just posterior to the adipose-fin membrane to the caudal fin). In case of missing teeth, the space left was counted as a tooth. Standard length (SL) is expressed in $\mathrm{mm}$. All other measurements are expressed as percents of standard length, except subunits of the head, which are expressed as percents of head length (HL). Scanning Electron Microscope (SEM) images were obtained from teeth.

The specimens examined belong to the American Museum of Natural History, New York (AMNH), The Natural History Museum, London (BMNH), Ichthyological Collection of the Laboratório de Ictiologia Sistemática, Departamento de Ecologia e Biologia Evolutiva, Universidade Federal de São Carlos, São Carlos (LISDEBE), Museu de Ciências e Tecnologia, Pontifícia Universidade Católica do Rio Grande do Sul, Porto Alegre (MCP), Muséum d'Histoire Naturelle, Geneve (MHNG), Muséum d'Histoire Naturelle, Paris (MNHN), Museu Nacional, Rio de Janeiro (MNRJ), Museu de Zoologia, Universidade Estadual de Londrina, Londrina (MZUEL), Museu de Zoologia, Universidade de São Paulo, São Paulo (MZUSP) and Ichthyological Collection of Núcleo de Pesquisa em Limnologia, Ictiologia e Aqüicultura, Universidade Estadual de Maringá, Maringá (NUP).

\section{Hypostomus multidens, new species}

Fig. 1

Holotype. MZUEL 4712, 195.4 mm SL, Brazil, State of Paraná, Londrina, distrito de Maravilha, rio Tibagi basin, rio Taquara, at its mouth, 2330'51'"S/5057'18'”, 31 Jul 2006; W. Galves et al.

Paratypes. ANSP 187121, (2) 184.4-193.2 mm SL, Brazil, State of São Paulo, Cândido Mota, rio Paranapanema, 1992. MZUEL 4497, (2) 177.3-185.9 mm SL, same data as holotype. Brazil: State of Paraná: MZUEL 152, (1) 155.4 mm SL, Sertanópolis, rio Tibagi, 17 Feb 1991. MZUEL 153, (1) 131.3 mm SL, Sapopema, rio Tibagi, 25 Feb 1991. MZUEL 154, (1) 163.5 mm SL, Londrina, rio Tibagi basin, Ribeirão Cambé, 06 Oct 1990. MZUEL 2100, (1) $109.8 \mathrm{~mm}$ SL, Porecatu, rio Paranapanema, 1992. MZUEL 2101, (1) 197.5 mm SL, rio Paranapanema, 1992. MZUEL 3388, (2) 140.9-143.8 mm SL, rio Pardo, 12 Nov 2000; S. Britto. MZUSP 93883, (2) 149.3-171.0 mm SL, Porecatu, rio Paranapanema, 1992. NUP 2561, (5) 96.3-155.4 mm SL, Guaíra, rio Paraná, Itaipu Reservoir, 2500’S/ 54 ${ }^{\circ} 15^{\prime} \mathrm{W}, 1983-1993$. NUP 4821, (2) 160.0-169.3 mm SL, Tibagi, rio Tibagi, 18 Feb 2002; A. M. Geahl. NUP 4829, (1) 184.3 mm SL, Guaíra, rio Paraná, 27 Jul 2002; T. Becker. State of São Paulo: LISDEBE 1966, (2) 181.7-188.8 mm SL, Piraju, rio Paranapanema, 10 Jul 2000; J. C. Garavello, A. K. Oliveira. LISDEBE 1967, (1) 160.4 mm SL, Ourinhos, rio Paranapanema, 29 Nov 2004; J. C. Garavello, A. K. Oliveira, A. S. Soares. LISDEBE 1968, (1) 145.8 mm SL, Ourinhos, rio Paranapanema, 2306'17'S/4945'46"W, 16 May 2006; J. C. Garavello, F. Apone, H. R. Varella.

Diagnosis. Hypostomus multidens is distinguished from all remaining congeners with light spots on a darker background by two independent characters: the presence of teeth with two symmetrical cusps (vs. two asymmetrical cusps in $H$. albopunctatus, $H$. lexi, H. margaritifer, $H$. meleagris, $H$. microstomus, $H$. regani, $H$. scaplyceps, $H$. strigaticeps, $H$. tietensis, and $H$. variipictus), and a high tooth number in each mandibular ramus $(122-267$, mean $=196.8 ;$ vs. 127 teeth at most, in $H$. ternetzi, the congener with highest tooth number in each mandibular ramus from upper rio Paraná basin).

Description. Counts and proportional measurements presented in Table 1. Dorsal surface of body covered with plates except for narrow area around dorsal fin insertion. Body gradually narrower from cleithrum to caudal fin. Dorsal profile of body convex, rising in straight line from snout tip to supraoccipital, then as a ridge until dorsal-fin origin; descending from this point to caudal-fin base. Body mostly ovoid in cross-section, and slightly flattened ventrally. Caudal peduncle robust and roughly ovoid in cross-section, slightly flattened on ventral portion with shallow concave area posterior to anal-fin insertion, more compressed caudally. Greatest body depth at dorsal-fin origin. Ventral surface of head usually naked, sometimes with platelets anterior to gill openings; abdomen covered with minute platelets at line of pectoral girdle and anterior of urogenital opening, some specimens with plated area expanded to center of abdomen.

Head broad, anterior profile roundish or moderately roundish in dorsal view. Snout depressed with naked area without odontodes on its tip. Three slightly longitudinal ridges between orbits and snout tip, lateral ridges more prominent. 
Dorsal region between orbits concave; upper margin of orbits elevated. Supraoccipital bordered posteriorly by first predorsal plate, its dorsal surface convex with ridge that increases through predorsal plates until dorsal-fin origin. Dorsal plates between end of dorsal-fin base and first unpaired preadipose plate flattened; first ones without odontodes on their median line. Mid-dorsal and medial series of plates more keeled until middle of dorsal-fin base. Mid-ventral series of plates keeled until beginning of ventral series of plates. First anal-fin proximal radial exposed, forming flat plate anterior to first anal-fin ray. Most lateral body plates with weak odontodes on posterior border.

Eye moderately large, dorsolaterally placed. Iris with minute dorsal flap covering pupil. Mouth with short, narrow buccal papilla. Oral disc wider than longer and well developed, occupying most of ventral surface of head. Lower lip reaching gill opening and covered with minute papillae, that decrease in size towards lips edge. Maxillary barbel short, coalesced with lower lip and ornamented with small papillae. Teeth thin, bicuspid with symmetrical cusps, in high number and very small size; slightly curved inwards (Fig. 2). Opercular region not very mobile, with few hypertrophied odontodes. Cleithrum exposed and in contact with ventral border of pteroticsupracleithrum, pointed cleithral process extending above pectoral-fin insertion.

Nuchal plate present; dorsal-fin spinelet present and locking mechanism functional. Dorsal-fin origin at vertical line halfway from pectoral to pelvic-fin insertions. Last branched dorsal-fin ray reaching adipose-fin spine. Dorsalfin spine moderately flexible on distal portion. Adipose fin

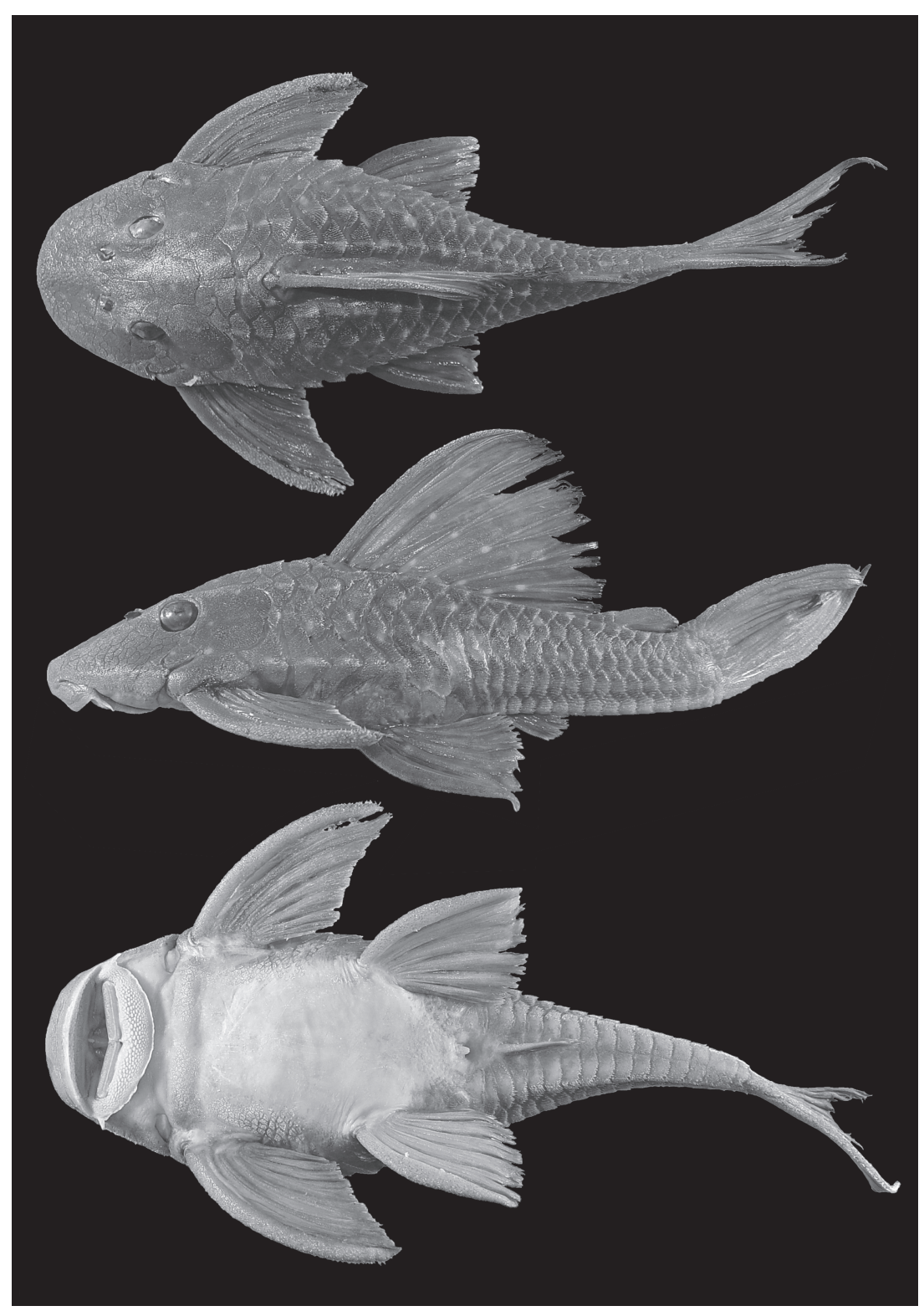

Fig. 1. Hypostomus multidens, holotype, MZUEL 4712, 195.4 mm SL, Brazil, State of Paraná, Londrina, distrito de Maravilha, rio Tibagi basin, rio Taquara. 
present and slightly curved, preceded by unpaired pre-adipose azygous plates. Pectoral-fin spine slightly curved, with hypertrophied odontodes curved forward on its distal tip. First and second branched rays as long as spine. Subsequent branched rays gradually decreasing in size. Posterior margin of pectoral fin straight, surpassing about one third of pelvic fin when adpressed. Pelvic-fin spine reaching first half of anal fin when adpressed, covered with minute odontodes ventrally and laterally. Posterior margin of pelvic fin slightly roundish. First anal-fin ray unbranched, reaching sixth plate after its origin. Distal profile of caudal fin concave, lower lobe longer than upper.
Color in alcohol. Ground color of dorsal surface of head and body brown or grayish brown; pale yellow ventrally. Dorsal surface of head with blotches slightly smaller and closer to each other than those on posterior portion of body. Dorsum and flanks covered with light roundish blotches, equally spaced and with almost pupil size. Blotches present on fins, including interradial membranes. Ventral margin of head and outer portion of upper lip homogeneously light brownish; ventral portion of caudal peduncle dusky. Spines of dorsal, pectoral, pelvic, anal and caudal fins grayish brown (Fig. 3).

Table 1. Morphometrics and meristics data of the holotype and paratypes of Hypostomus multidens $(\mathrm{N}=26$ including the holotype).

\begin{tabular}{|c|c|c|c|c|c|c|}
\hline Character & Holotype & Minimum & Maximum & Mean & $\mathrm{SD}$ & $\mathrm{N}$ \\
\hline Standard length (mm) & 195.3 & 96.3 & 197.5 & - & - & 26 \\
\hline \multicolumn{7}{|c|}{ Percents of standard length } \\
\hline Head length & 32.6 & 30.8 & 35.2 & 32.9 & 1.2 & 26 \\
\hline Predorsal length & 41.5 & 35.5 & 43.1 & 40.8 & 1.6 & 26 \\
\hline Dorsal-fin base length & 31.5 & 30.1 & 43.2 & 33.2 & 2.7 & 26 \\
\hline Distance between end of dorsal-fin and adipose-fin & 14.4 & 10.7 & 17.6 & 13.7 & 1.3 & 26 \\
\hline Posdorsal length & 31.2 & 29.8 & 34.6 & 32.1 & 1.2 & 26 \\
\hline Dorsal-fin spine length & 35.1 & 22.7 & 38.5 & 31.9 & 4.6 & 25 \\
\hline Anal-fin spine length & 9.9 & 9.8 & 12.2 & 11.1 & 0.6 & 26 \\
\hline Pectoral-fin spine length & 33.0 & 28.5 & 37.0 & 33.3 & 2.4 & 26 \\
\hline Pelvic-fin spine length & 25.2 & 19.9 & 28.2 & 25.4 & 2.1 & 26 \\
\hline Adipose-fin spine length & 9.8 & 7.6 & 11.3 & 9.8 & 0.9 & 25 \\
\hline Upper caudal-fin ray & 26.9 & 20.3 & 46.4 & 31.2 & 6.7 & 11 \\
\hline Lower caudal-fin ray & 36.7 & 32.2 & 40.3 & 34.8 & 2.4 & 15 \\
\hline Trunk length & 25.8 & 21.2 & 27.0 & 24.4 & 1.5 & 26 \\
\hline Abdominal length & 23.0 & 21.3 & 28.0 & 23.0 & 1.3 & 26 \\
\hline Body depth at dorsal origin & 27.2 & 19.3 & 27.2 & 22.4 & 2.0 & 26 \\
\hline Body width at dorsal origin & 34.9 & 26.8 & 34.9 & 30.7 & 2.1 & 26 \\
\hline Body width at anal origin & 21.6 & 13.6 & 21.6 & 17.8 & 1.9 & 26 \\
\hline Caudal peduncle length & 32.4 & 30.1 & 35.2 & 32.5 & 1.0 & 26 \\
\hline Caudal peduncle depth & 11.5 & 10.2 & 12.3 & 11.4 & 0.6 & 26 \\
\hline Caudal peduncle width & 6.2 & 4.8 & 6.5 & 5.6 & 0.4 & 26 \\
\hline Total length & 136.6 & 121.3 & 142.1 & 135.0 & 4.3 & 16 \\
\hline Axial length & 119.9 & 108.7 & 124.8 & 118.8 & 3.8 & 24 \\
\hline \multicolumn{7}{|c|}{ Percents of head length } \\
\hline Cleithral width & 106.6 & 96.8 & 113.1 & 104.6 & 4.4 & 26 \\
\hline Head depth & 67.1 & 53.5 & 70.2 & 60.7 & 4.5 & 26 \\
\hline Snout length & 61.7 & 59.4 & 65.3 & 61.8 & 1.5 & 26 \\
\hline Eye-nostril distance & 10.9 & 7.7 & 11.7 & 9.9 & 1.2 & 26 \\
\hline Least internostril width & 14.2 & 12.7 & 15.9 & 14.2 & 0.8 & 26 \\
\hline Orbital diameter & 19.9 & 18.1 & 23.1 & 20.7 & 1.2 & 26 \\
\hline Least interorbital width & 35.5 & 27.4 & 40.5 & 33.9 & 2.9 & 26 \\
\hline Oral disk width & 67.4 & 57.6 & 69.2 & 64.8 & 2.8 & 26 \\
\hline Mandibular ramus & 25.6 & 21.3 & 28.6 & 25.6 & 1.8 & 26 \\
\hline Rictal barbel length & 10.4 & 9.2 & 18.4 & 13.6 & 2.6 & 26 \\
\hline \multicolumn{7}{|c|}{ Counts } \\
\hline Median plates series & 25 & 24 & 26 & 25.3 & 0.6 & 26 \\
\hline Predorsal plates & 3 & 3 & 3 & 3.0 & 0.0 & 26 \\
\hline Dorsal plates below dorsal-fin base & 9 & 8 & 10 & 8.8 & 0.6 & 26 \\
\hline Plates between dorsal/adipose & 6 & 3 & 7 & 5.0 & 0.8 & 26 \\
\hline Plates between adipose/caudal & 6 & 4 & 6 & 5.0 & 0.7 & 26 \\
\hline Ventral plates above anal-fin base & 2 & 1 & 2 & 1.9 & 0.3 & 26 \\
\hline Ventral plates between end of anal-fin base and caudal-fin & 15 & 13 & 15 & 14.2 & 0.8 & 26 \\
\hline Dorsal median unpaired plates & 3 & 1 & 5 & 2.5 & 0.8 & 26 \\
\hline Dentary teeth & 216 & 122 & 267 & 196.8 & 38.5 & 24 \\
\hline Premaxillary teeth & 220 & 115 & 260 & 190.8 & 43.7 & 26 \\
\hline Dorsal-fin branched rays & 7 & 7 & 8 & 7.0 & 0.2 & 26 \\
\hline Anal-fin branched rays & 4 & 3 & 5 & 4.0 & 0.3 & 26 \\
\hline Caudal-fin branched rays & 12 & 12 & 15 & 14.0 & 0.4 & 26 \\
\hline Pectoral-fin branched rays & 6 & 6 & 6 & 6.0 & 0.0 & 26 \\
\hline Pelvic-fin branched rays & 5 & 5 & 5 & 5.0 & 0.0 & 26 \\
\hline
\end{tabular}




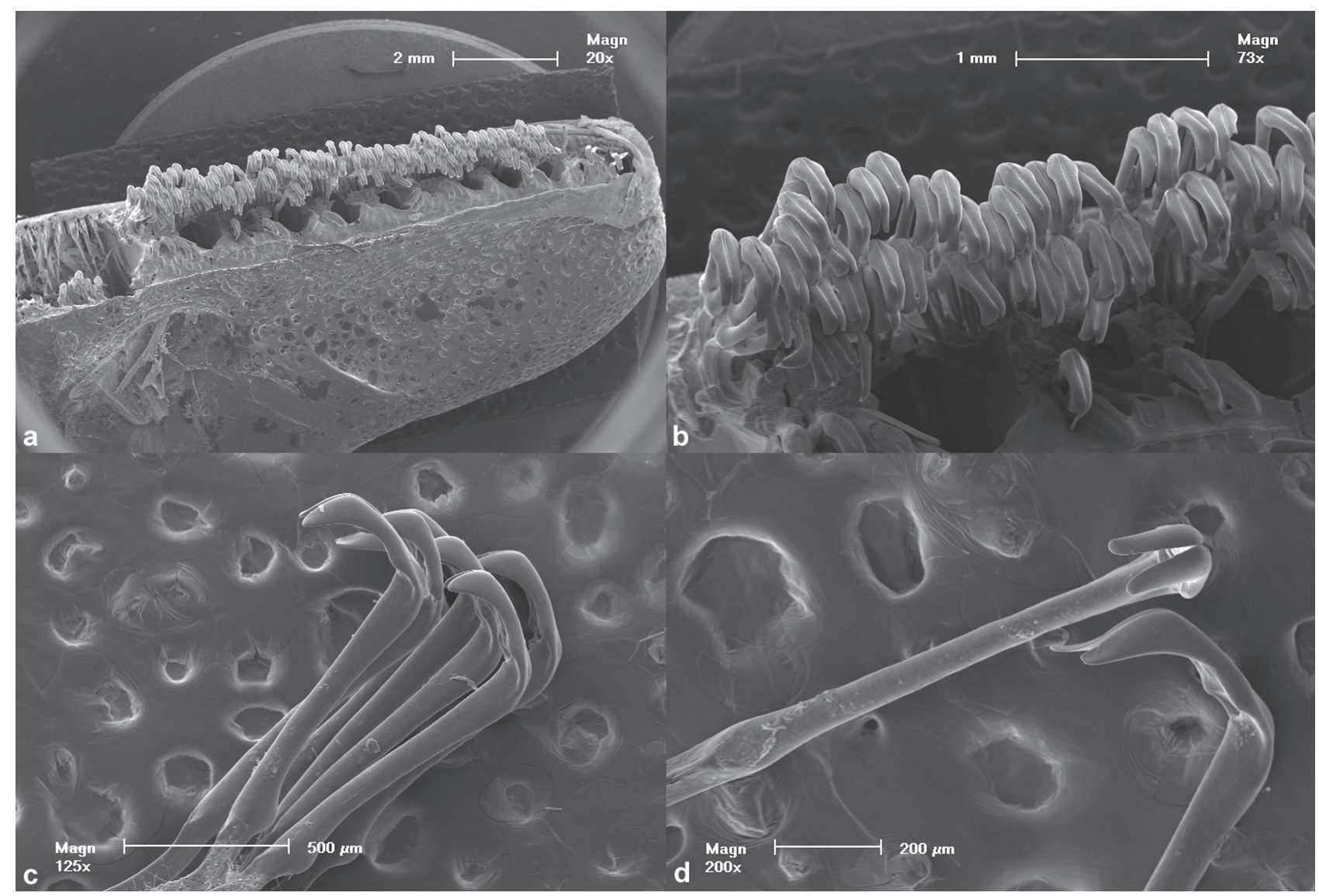

Fig. 2. SEM photographs of Hypostomus multidens left dentary teeth. Partial ventral view of dentary (a). Ventral view of emergent teeth rows (b). Lateral view of teeth symmetrical cusps (c). Frontal view of tooth crown with symmetrical cusps (left), and lateral view of tooth crown with partially broken cusp (d). All photographs were taken from the paratype MZUEL 4497, $177.3 \mathrm{~mm}$ SL, same data as holotype.

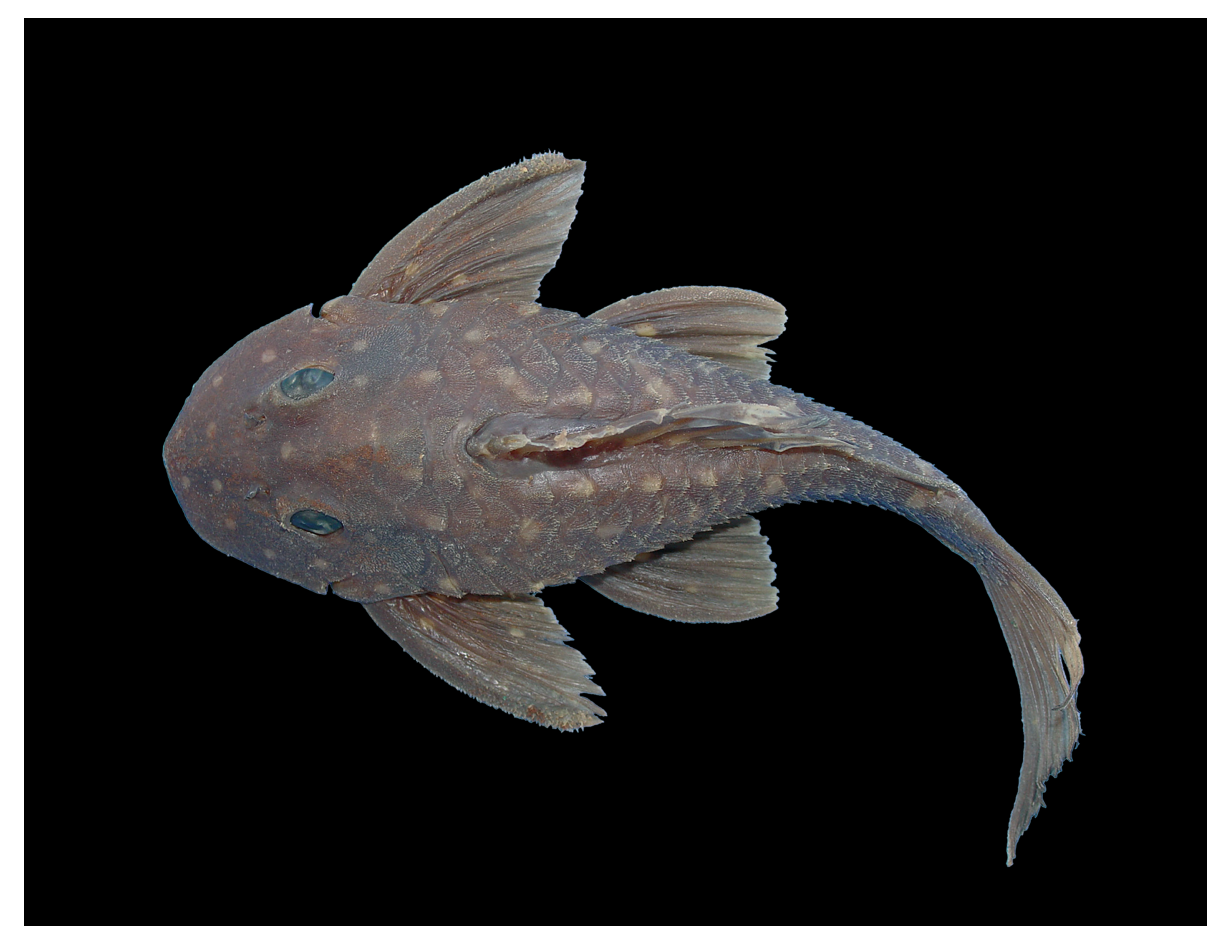

Fig. 3. Color pattern of Hypostomus multidens, paratype, MZUEL 3388, 140.9 mm SL, Brazil, State of São Paulo, rio Pardo. 
Color in life. Ground color of upper surface of head and body black or grayish black; pale gray ventrally. Blotch color ranges from vibrant yellow to orange.

Distribution. Hypostomus multidens is known from several localities in the rio Paranapanema basin in the states of São Paulo and Paraná. It was also found in the rio Paraná in the transition from rapid to still waters at the beginning of the Itaipú Reservoir lake in the city of Guaíra (Fig. 4).

Ecological notes. Specimens of Hypostomus multidens were so far found in large rivers, and are usually collected in low number, justifying their rarity in museum collections. We have recently conducted a survey on its type-locality (rio Taquara) and only three specimens were caught, representing $3.7 \%$ of all Hypostomus specimens collected. The other loricariid species collected with Hypostomus multidens were: Hypostomus ancistroides, $H$. hermanni, $H$. iheringii, $H$. margaritifer, $H$. regani, $H$. strigaticeps, Loricaria prolixa Isbrücker \& Nijssen, 1978 and Megalancistrus parananus (Peters, 1881).

Etymology. The specific epithet multidens (Latin) is given in allusion to the high number of teeth (multus, many + dens, teeth).

\section{Discussion}

Tooth morphology and the high number of teeth, both distinguish Hypostomus multidens from all remaining species of Hypostomus (Fig. 2). Notwithstanding, H. multidens can also be recognized by the concurrent presence of non-

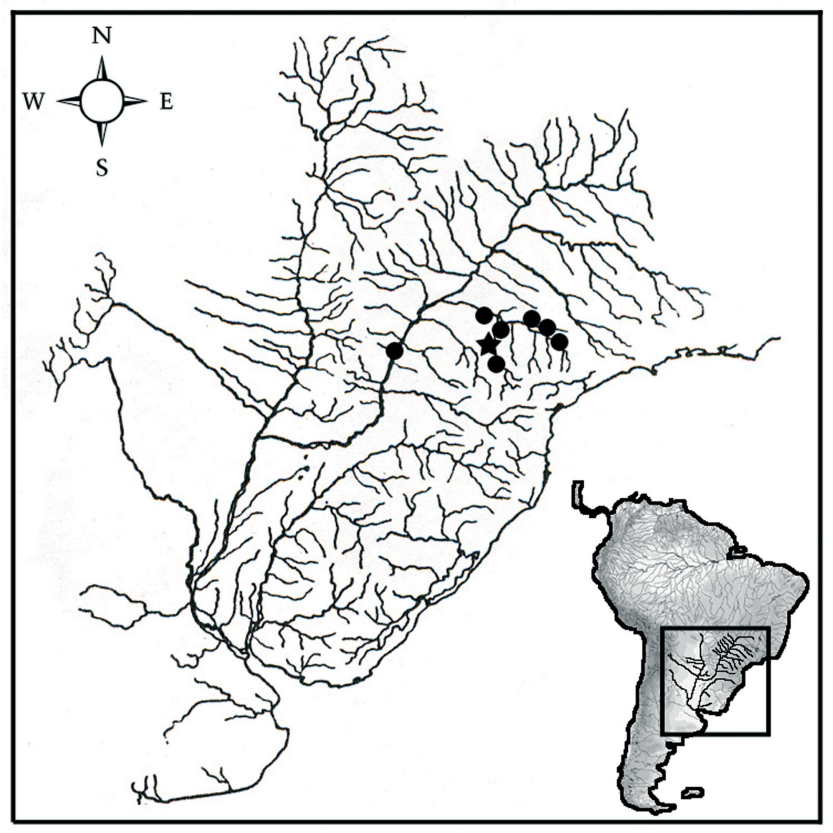

Fig. 4. Southeastern portion of South America showing distribution of Hypostomus multidens in the upper rio Paraná basin $\left(\right.$ star $=$ type-locatily $\left.23^{\circ} 30^{\prime} 51^{\prime \prime} \mathrm{S} / 50^{\circ} 57^{\prime} 18^{\prime \prime} \mathrm{W}\right)$. Each dot can represent more than one locality or lot. exclusive characters, such as: the color pattern; stout body; short, flat and round snout; large eyes with orbital ridges; a ridge on supraocciptal plates; large mandible (21.3 to $28.7 \%$ HL); and high number of weak odontodes on the body plates (Fig. 1).

Hypostomus multidens is very similar to the $H$. ternetzi species group (Zawadzki et al., 2005) in external morphology. Despite the dark spots present in the species of that group, H. multidens match all external morphological traits proposed by those authors, including wide jaw, deep caudal peduncle, supraoccipital process and predorsal plates forming a medium crest, and abdominal plates restricted to the anterior portion of the abdomen or with extensive naked areas around pelvicfin insertions.

The large and widely-spaced light spots (Fig. 3) not only distinguish $H$. multidens from the dark spotted species from the upper rio Paraná basin (H. ancistroides, H. brevis, $H$. commersoni, H. fluviatilis, $H$. hermanni, H. iheringii, $H$. nigromaculatus, $H$. paulinus, $H$. ternetzi and $H$. topavae), but also from the Hypostomus with small closely-spaced light spots ( $H$. albopunctatus, $H$. lexi, $H$. margaritifer, $H$. meleagris, $H$. regani, $H$. scaplyceps, $H$. strigaticeps, $H$. tietensis and $H$. variipictus) present in the same basin. Among the species with light spots on a darker ground, only $H$. microstomus have a similar spot pattern, but differs from $H$. multidens in tooth shape (stout teeth with asymmetric cusps) and low teeth number (approximately eight to 16, according to Weber, 1987).

The tooth number in the mandibular ramus is highly variable among Hypostomus (Muller \& Weber, 1992). In the upper rio Paraná basin, Hypostomus ternetzi $(\mathrm{n}=20$, dentary: 40-126 teeth, mean 83.7; premaxilla: 39-127 teeth, mean 79.0) show a high number of teeth per mandibular ramus. However, among species with light spots on the body Hypostomus regani is known by having the highest number of teeth (dentary: 63-104 teeth, mean 81.5; premaxilla: 63-107 teeth, mean 81.3 ), followed by $H$. paulinus (dentary: $42-99$ teeth, mean 73.3; premaxilla: 50-96 teeth, mean 75.6) and $H$. strigaticeps (dentary: 57-101 teeth, mean 71.4; premaxilla: 5079 teeth, mean 66.0), but none of them overlapped the tooth number of $H$. multidens (Fig. 5).

Tooth shape is also variable among hypostomines, and some extreme forms characterize taxa (Muller \& Weber, 1992). The presence of teeth with two symmetrical cusps in Hypostomus multidens is a feature absent in all known species of Hypostomus, whose teeth have two asymmetrical cusps. Symmetrical cusps is not common among the Loricariidae, and in his phylogenetic analysis of the loricariid subfamilies, Schaefer (1987) considered the symmetrically-bifid teeth of Astroblepidae primitive relative to the derived asymmetrically bifid teeth of Loricariidae. Although almost symmetricallybifid teeth are also present in the basal loricariid subfamilies Lithogeninae (Provenzano et al., 2003; Schaefer, 2003) and Delturinae (Reis et al., 2006), the presence of a similar structure in $H$. multidens is not necessarily evidence that we are dealing with a basal species. According to the most recent 

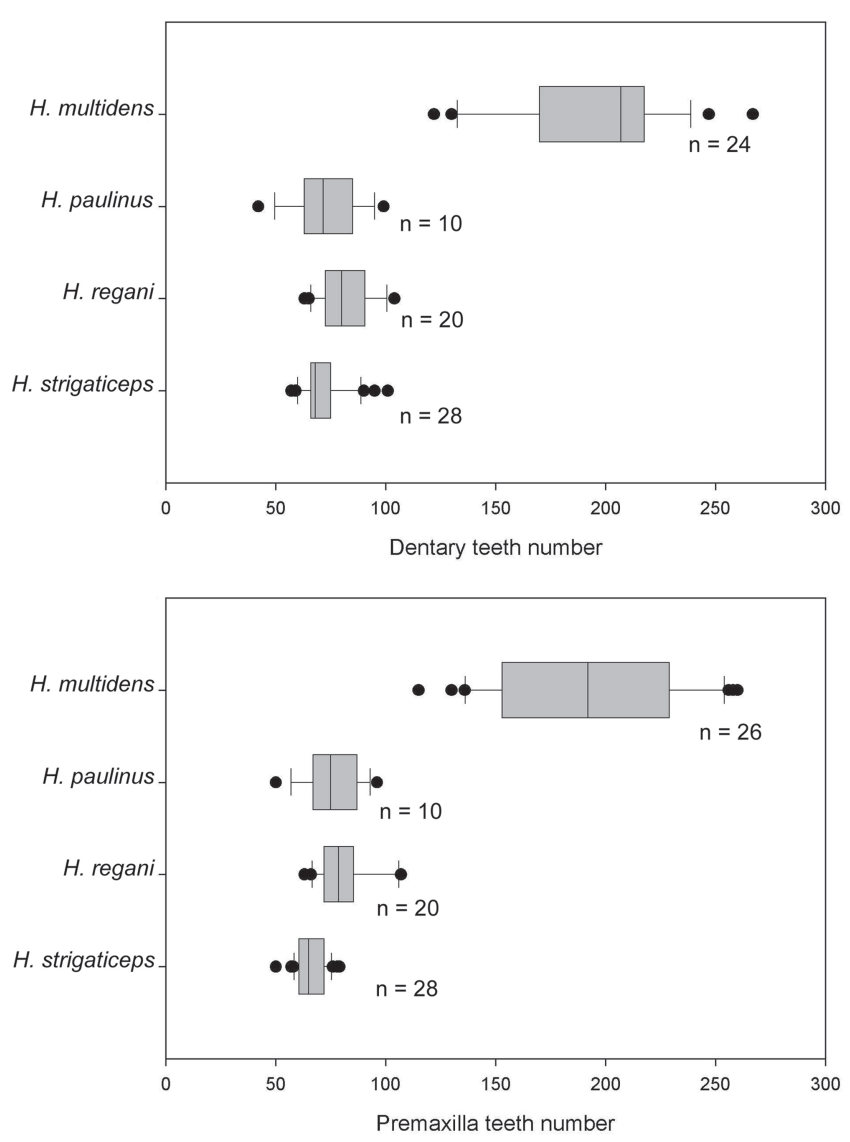

Fig. 5. Box plots of the number of dentary and premaxillary teeth $(n=$ number of specimens analyzed $)$.

phylogenetic analyses including the Loricariidae subfamilies (Armbruster, 2004; Reis et al., 2006), it is more parsimonious to consider the presence of symmetrically-bifid teeth in a Hypostomus species a homoplastic feature, rather than the maintenance of a plesiomorphic character or closer relationship between derived Hypostominae and basal Lithogeninae and Delturinae.

Despite some evidence, the position of $H$. multidens inside Hypostomini and its connection with $H$. ternetzi group, is yet to be evaluated in a phylogenetic study that includes the species of Hypostomus.

Material examined for count of teeth. (All from Brazil, upper rio Paraná basin): Hypostomus paulinus: State of São Paulo: BMNH 1905.6.9.4, (1) $135.0 \mathrm{~mm}$ SL, rio Piracicaba. MHNG 2599.058, (10) 83.2-127.1 mm SL, Salto Piracicaba. Hypostomus regani: State of Paraná: MZUEL 131, (1) $102.2 \mathrm{~mm}$ SL, rio Tibagi. MZUEL 1475, (1) $111.2 \mathrm{~mm}$ SL, rio Tibagi. MZUEL 200, (2) rio Tibagi. MZUEL 2431, (2) 104.0-111.0 mm SL, Foz do rio Itararé. MZUEL 198, (2) 154.8-156.5 mm SL, rio Tibagi. MZUEL 133, (1) 213.5 $\mathrm{mm}$ SL, rio Tibagi. MZUEL 2106, (9) 175.2-237.6 mm SL, rio Paranapanema. State of São Paulo: MZUEL 2107, (15) 140.6-215.6 mm SL, rio Turvo. Hypostomus strigaticeps: State of Paraná: MZUEL 3438, (1)121.8 mm SL, rio Paranapanema. MZUEL 3707, (1) 242.7 $\mathrm{mm}$ SL, ribeirão Jacutinga, rio Tibagi basin. MZUEL 3782, (15), ribeirão dos Apertados, rio Tibagi basin. MZUEL 2620, (1) 122.9 mm SL, rio Apucaraninha, rio Tibagi basin. MZUEL 2114, (1) 115.9 $\mathrm{mm}$ SL, tributário Salto Grande, rio Paranapanema basin. MZUEL 2096, (1) $83.5 \mathrm{~mm}$ SL, rio Paranapanema. State of São Paulo: MZUEL 3736, (1) $116.1 \mathrm{~mm}$ SL, rio Paranapanema. MZUEL 2094, (9) 66.4-140.0 mm SL, rio Claro. MZUEL 2118, (1) $85.8 \mathrm{~mm} \mathrm{SL}$, ribeirão Claro. MZUEL 3708, (5) 149.3-179.7 mm SL, rio Paranapanema. Hypostomus ternetzi: State of Paraná: NUP 1765, (20) 157.0-296.0 mm SL, reservatório de Itaipu, rio Paraná.

Comparative material. Hypostomus albopunctatus: BMNH 1907.7.6.15, (2) 134.1-169.0 mm SL, lectotype, rio Piracicaba, São Paulo State, Brazil. H. ancistroides: MZUSP 2131, (4) 95.6-165.1 mm SL, rio Tatuí, São Paulo State, Brazil. H. boulengeri: NUP 414, (3) 165.8-175.6 mm SL, rio Manso, Mato Grosso State, Brazil. H. carvalhoi: MNRJ 28870, (2) 95.0-105.1 mm SL, syntypes, rio Jaguaribe, Ceará State, Brazil. H. cochliodon: NUP 3602, $153.8 \mathrm{~mm}$ $\mathrm{SL}$, rio Manso, rio Paraguai basin, Mato Grosso State, Brazil. $H$. commersoni: MNHN A.9444, $425.0 \mathrm{~mm} \mathrm{SL}$, holotype, rio de la Plata, Uruguay. H. cordovae: BMNH 1878.4.4.1, 178.3 mm SL, holotype, rio Paraná, Cordova, Argentina. H. derbyi: NUP 1791, (7) 126.4-225.6 mm SL, rio Iguaçu, Paraná State, Brazil. H. dlouhyi: MHNG 2229.43, 139.5 mm SL, holotype, rio Yguazú (non Iguaçú), Paraguay. H. fluviatilis: MZUSP 25704, $152.0 \mathrm{~mm}$ SL, rio Pardo, São Paulo State, Brazil. H. hermanni: BMNH 1905.6.9.5, 201.8 $\mathrm{mm}$ SL, holotype, rio Piracicaba, São Paulo State, Brazil. H. iheringii: BMNH 1907.7.6.13, 115.9 mm SL, holotype, rio Piracicaba, São Paulo State, Brazil. H. interruptus: MZUSP 2110, $119.5 \mathrm{~mm}$ SL, holotype, rio Juquiá, São Paulo State, Brazil. H. isbrueckeri: MZUSP 40257, (2) 172.3-176.6 mm SL, syntypes, rio Uruguay, Rio Grande do Sul State, Brazil. H. laplatae (=H.taeniatus): BMNH 1908.8.29.17, $207.3 \mathrm{~mm}$ SL, syntype, rio La Plata, Argentina. $H$. latifrons: MHNG 2256.67, 228.2 mm SL, holotype, rio Araguayguazú, Paraguay. H. latirostris: BMNH 1892.4.20.26-27, (2) 137.2$159.3 \mathrm{~mm}$ SL, syntypes, rio Jangada, Mato Grosso State, Brazil. H. lexi: MZUSP 2126, $353.0 \mathrm{~mm}$ SL, holotype, São Paulo State, Brazil. H. luteus: MHNG 2430.072, $241.1 \mathrm{~mm}$ SL, Rio Grande do Sul State, Brazil. H. margaritifer: BMNH 1907.7.6.14, $120.7 \mathrm{~mm}$ SL, holotype, rio Piracicaba, São Paulo State, Brazil. H. meleagris: AMNH 12249, 193.7 mm SL, syntype (1 of 4), South-eastern Brazil. H. microstomus: MHNG 2367.90, 197.5 mm SL, holotype, dpt Itapua, Paraguay. H. mutucae: MCP 28669, 67.7 mm SL, holotype, rio Mutuca, Mato Grosso State, Brazil. H. myersi: NUP 2916, 120.7 mm SL, rio Iguaçu, Paraná State, Brazil. H. nigromaculatus: MZUSP 22674, (9) 43.8-75.9 mm SL, rio MogiGuaçu, Cachoeira de Emas, São Paulo State, Brazil. H. paulinus: BMNH 1905.6.9.4, 135.0 mm SL, holotype, rio Piracicaba, São Paulo State, Brazil. H. piratatu: MHNG 2265.03, 214.0 mm SL, holotype, dep. Paraguari, Paraguay. H. regani: BMNH 1905.6.7.2, 174.2 mm SL, holotype, rio Piracicaba, São Paulo State, Brazil. $H$. rondoni: MNRJ 741, $64.6 \mathrm{~mm} \mathrm{SL}$, holotype, rio São Manuel, rio Tapajós basin, Mato Grosso State, Brazil. H. roseopunctatus: MHNG 2414.010, 119.8 mm SL, paratype, rio Comandai, Rio Grande do Sul State, Brazil. H strigaticeps: BMNH 1907.6.10-11, (2) 110.9-160.0 mm SL, syntypes, rio Piracicaba, São Paulo State, Brazil. H. tapijara: NUP 2795, (3) 174.9-193.2 mm SL, rio Capivari, Ribeira de Iguape basin, Paraná State, Brazil. H. ternetzi: BMNH 1895.5.17.64, 210.2 mm SL, holotype, rio Paraguai, Mato Grosso State, Brazil. H. tietensis: BMNH 1905.6.9.1, 127.9 mm SL, holotype, rio Tietê, São Paulo State, Brazil. H. topavae: MZUSP 44713, (2) 102.1-117.0 mm SL, rio Mogi-Guaçu, São Paulo State, Brazil. H. variipictus: MZUSP 2114, $298.0 \mathrm{~mm} \mathrm{SL}$, holotype, rio Pardo, São Paulo State, Brazil. 


\section{Acknowledgments}

The authors are grateful to Roberto Esser dos Reis and Luiz Roberto Malabarba (Museu de Ciências e Tecnologia, PUCRS) for comments and suggestions on the manuscript. Thanks to Mônica Toledo-Piza, Claude Weber, and two anonymous referees for the reviews. Special thanks to Edson Santana, Aparecido de Souza and Wanner Galves for their help on fieldwork. SEM photographs were taken at "Centro de Microscopia e Microanálises", PUCRS. This paper is part of the Master thesis of F. C. Jerep supported by CAPES and Programa de Pós-graduação da Universidade Estadual de Londrina. Licence for fish collection was granted IBAMA (licence nb. 083/2003). The authors are collaborators of the Planetary Biodiversity Inventory: All Catfish Species (Siluriformes) - Phase I of an Inventory of the Otophysi (NSF DEB-0315963). Hypostomus type analysis was partially benefited from ACSI grants, support 07-04.

\section{Literature Cited}

Armbruster, J. W. 2004. Phylogenetic relationships of the suckermouth armoured catfishes (Loricariidae) with emphasis on the Hypostominae and the Ancistrinae. Zoological Journal of the Linnean Society, 141: 1-80.

Boeseman, M. 1968. The genus Hypostomus Lacépède, 1803, and its Surinam representatives (Siluriformes, Loricariidae). Zoologische Verhandelingen, 99: 1-89.

Fisch-Muller, S., R. Mazzoni \& C. Weber. 2001. Genetic and morphological evidences for two new sibling species of Ancistrus (Siluriformes: Loricariidae) in upper rio Tocantins drainage, Brazil. Ichthyological Exploration of Freshwaters, 12(4): 289-304.

Hollanda Carvalho, P. \& C. Weber. 2004. Five new species of the Hypostomus cochliodon group (Siluriformes: Loricariidae) from the middle and lower Amazon System. Revue Suisse de Zoologie, 111: 953-978.

Ihering, R. von. 1905. Description of four new loricariid fishes of the genus Plecostomus from Brazil. The Annals and Magazine of Natural History, 15(7): 558-561.

Mazzoni, R., U. Caramaschi \& C. Weber. 1994. Taxonomical revision of the species of Hypostomus Lacépède, 1803 (Siluriformes, Loricariidae) from the Lower rio Paraíba do Sul, State of Rio de Janeiro, Brazil. Revue Suisse de Zoologie, 101(1): 3-18.

Muller, S. \& C. Weber. 1992. Les dents des sous-familles Hypostominae et Ancistrinae (Pisces, Siluriformes, Loricariidae) et leur valeur taxonomique. Revue Suisse de Zoologie, 99(4): 747-754.
Oyakawa, O. T., A. Akama \& A. M. Zanata. 2005. Review of the genus Hypostomus Lacépède, 1803 from rio Ribeira de Iguape basin, with description of a new species (Pisces, Siluriformes, Loricariidae). Zootaxa, 921: 1-27.

Pereira, E. H. \& O. T. Oyakawa. 2003. Isbrueckerichthys epakmos, a new species of loricariid catfish from the rio Ribeira de Iguape basin, Brazil (Teleostei: Siluriformes). Neotropical Ichthyology, 1(1): 3-9.

Provenzano, F. R., S. A. Schaefer, J. N. Baskin, \& R. Royero-Leon. 2003. New, possibly extinct Lithogenine loricariid (Siluriformes, Loricariidae) from Northern Venezuela. Copeia, 2003(3): $562-575$.

Reis, R. E., E. H. L. Pereira \& J. W. Armbruster. 2006. Delturinae, a new loricariid catfish subfamily (Teleostei, Siluriformes), with revisions of Delturus and Hemipsilichthys. Zoological Journal of the Linnean Society, 147: 277-299.

Reis, R. E., C. Weber \& L. R. Malabarba. 1990. Review of the genus Hypostomus Lacépède, 1803 from southern Brazil, with descriptions of three new species (Pisces, Siluriformes, Loricariidae). Revue suisse de Zoologie, 97(3): 729-766.

Schaefer, S. A. 1987. Osteology of Hypostomus plecostomus (Linnaeus), with a phylogenetic analysis of the loricariid subfamilies (Pisces: Siluroidei). Contributions in Science, 394: $1-31$.

Schaefer, S. A. 1997. The neotropical cascudinhos: systematics and biogeography of the Otocinclus catfishes (Siluriformes: Loricariidae). Proceedings of the Academy of Natural Sciences of Philadelphia, 148: 1-120.

Schaefer, S. A. 2003. Relationships of Lithogenes villosus Eigenmann, 1909 (Siluriformes, Loricariidae): evidence from highresolution computed microtomography. American Museum Novitates, 3401: 1-55.

Weber, C. 1985. Hypostomus dlouhyi, nouvelle espèce de poissonchat cuirassé du Paraguay (Pisces, Siluriformes, Loricariidae) Revue suisse de Zoologie, 92(4): 955-968.

Weber, C. 1986. Revision de Hypostomus boulengeri (Eigenmann $\&$ Kennedy), et deux espèces nouvelles de poissons-chats du Paraguay (Pisces, Siluriformes, Loricariidae). Revue Suisse de Zoologie, 93(4): 979-1007.

Weber, C. 1987. Hypostomus microstomus sp. nov. et autres poissons-chat cuirassés du rio Parana (Pisces, Siluriformes, Loricariidae). Archives des Sciences, Genève, 40(3): 273-284.

Weber, C. 2003. Subfamily Hypostominae (Armored catfishes) Pp 351-372. In: Reis, R. E., S. O. Kullander \& C. J. Ferraris (Eds.). Check List of the Freshwater Fishes of South and Central America. Porto Alegre, Edipurcs, 729p.

Zawadzki, C. H., E. Renesto, R. E. Reis, M.O. Moura \& R. P. Mateus. 2005. Allozyme relationships in hypostomines (Teleostei: Loricariidae) from the Itaipu Reservoir, Upper rio Paraná basin, Brazil. Genetica, 123(3): 271-283. 